\title{
Skill Set, Cross Culture Competencies And Personality Traits Required To Be A Successful Expatriate
}

\author{
Hafiz Muhammad Moinul Aziz \\ Bahuddin Zakariya University Multan \\ Umar Akhtar \\ Allama Iqbal University Islamabad \\ AyeshaZahid \\ Allama Iqbal University Islamabad
}

\author{
Ahsan Nawaz \\ Hebei University
}

\begin{abstract}
In the past few decades lot of research has been done on expatriate's adjustment but there are few reviews on the expatriate success. This review detail the success of expatriates and characteristics required for expatriate to become successful in the cross cultural environment. This review identifies the skill set,crosscultural competencies and personality traits requirement and there contribution toward expatriate success.
\end{abstract}

Keywords: skill set, cross cultural competencies, personality traits, expatriate success

\section{Introduction}

In recent decades as the organizations are going beyond the borders to expand their business so the employees of the company have to adapt and operate effectively in the foreign country. If expatriate come to home country without completing the assignment then it will be considered as expatriate failure .Company has to bear this failure in the form of direct and in direct cost direct cost involve remuneration package, relocation and compensation indirect cost involve damage of company image and loss of sale (Alizee, B.Avrial. 2007).There is increasing need to identify skills set, personality traits and cross culture competencies for effective adjustment and success of expatriate. International experience is observed as an effective way to develop people's worldview and to raise better adaptability. The issue of modifying in an outside culture is a worry that has been with mankind all through the ages. In these days identifying the best traits and competencies for a successful expatriate is very important. The two components skills set and diverse capabilities can be created by the preparation however character characteristics are typically seen as recently settled in the person's life or inalienable. Along these lines, this last factor identifies with the determination procedure. Past research has discovered that somewhere in the range of 16 and $40 \%$ of all exile chiefs' arrival rashly from their remote assignments because of their terrible showing or disappointment in diverse modification.Executing presentation in a cross-social/traditional setting existsin subjectively diverse execution in place of culturally diverse settings, wherever people of specific traditional norms, sentient in a different nation (Ying \& Han, 2006). So, cross cultural competencies, skills set $\&$ personality traits identification are too much important for becoming a successful expatriate in host country.

\section{Literature Review}

\section{Skill Set for Expatriate}

Khan, Khan, \&Rahman(2011) It depends on the ability of an expatriate that how much he is keen to learn more skills and knowledge in another cultural. Skill set leads to higher cross culture competencies (Dan Wanga, 2014). In particular, abilities are stressed elect the best noticeable factors of execution, in place of exhibit the intuitiveplus social variations of expatriate to adjustment (Yoshitaka, 2010). The psychological outcomes of expatriates will be increased because of these abilities. And also they will get more effective about how they can manage their multicultural teams while doing international assignments. (Brown, 2008; Templer, 2010). To become a successful expatriate he must have technical skills and skills to adjust in host country. (Alizee B .Avrial, 2007).Technical skills are related to assignment of expatriate that he will use in the country where he is going to perform assignment and some non-technical skills used by expatriate in host country for staying successful in the cross cultural situation areSelfmaintenance skills, language skills, Communication skills, Interpersonal skills. Self-maintenance skills are crucial for expatriates. 
Research don't bolster the immediate impacts of perceptual aptitudes on diverse competency however demonstrate that perceptual abilities impact crossculture competency fundamentally by means of correspondence (Dan Wanga, 2014). Some findings advice that perceptual skills has great and direct influence on adjustment of expatriates (Seak \& Enderwick, 2008). The discoveries additionally exhibit that relational abilities don't affect diverse competency, yet may add to culturally diverse competency through communication abilities(Dan Wanga, 2014). Albeit a few investigations found social aptitudes as the most basic achievement factor for expatriate presentation (Templer, 2010). Only language fluency does not allowexpertise to become successful in the host country because there are lot of other communication problem in the cross cultural environment (Dan Wanga, 2014).

Samovar et al. (1981) Characterized intercultural correspondence as making, passing on, and translating imageriesoveroral and non-oralcanals among personalities thrunumerous state humanities. Language contrasts likewise have been seen as a slight utilitarian issue that effectively can be illuminated by interpreters, interpretation programming, or phonetically equipped representatives (Welch et al., 2005). However, another flood of writing proposes that dialects and social qualities can have various results in intercultural interchanges for a few reasons. Initial, a common unknown dialect may not ensure blunder free comprehension on the grounds that social qualities communicated through correspondence styles will in general go about as hindrances to seeing, breaking down, and deciphering express and certain messages (Dan Wanga, 2014). Social qualities affect noteencrypting and untying among senders and sundaes. Next, a person's capacity plus eagerness toward impart over etymological limits is identified with their unknown dialect skill (Stein, 1966). Normally we just focus on cultural values but in fact we need to focus on language as well. And research on language is also very poor. If an expatriate want to communicate effectively and want to deal with psychological stress effectively then he need to understand cross cultural competencies completely (Johnson et al., 2006).

\section{Cross Culture Competency}

Samovar et al. (1981) defined cross culture competency as the capability of peoples to work successfully in foreign culture. A person's prosperity is resolved upon a lot of information, aptitudes, and individual qualities to work effectively with individuals of various social foundations at home or host nation (Johnson et al., 2006). A developing stream of research bolsters that effective exile adjustment relies upon how well a director can gain for a fact in abroad assignments (Porter \&Tansky, 1999). A few analysts state that situational elements assume a more significant job in Intercultural Effectiveness than aptitudes and character/Personality attributes (Hannigan, 1990).

According to (Yoshitaka Yamazaki, 2004) some cross cultural competencies are 1-Building relationships with others. This competency is acknowledgedby cultivating and producingsocial connections: dealingpersons (Byrnes, F. 1965)buildingrelations with nativepersonsplusbuddies (Stein, M. 1966). 2-Giving value to the peoples having different backgrounds or cultures. These competencies have been described in various ways including cultural empathy (Cleveland,1960); sense of humor (Stoner, 1972); cordiality (Harris, 1973); interpersonal respect (Hawes, 1979); intercultural sympathy (Hawes \&Kealey, 1979);sympathy inforeign country (Hawes, 1981); spare-social receptiveness (Bennett\& Arthur, 1995); and more prominent affectability to necessities of others (Tung, 1998). 3-Information skills. Listening and observation has been shared into four areas on cross-cultural eruditionabilities(Hawes, 1979); Choose to listen others (Tung, 1998);remark\&snooping (Ratiu, 1983).4-Coping with ambiguity. Understanding problematic situations from multiple of cross-cultural competencies. Competencies involvecapabilities to handle with vagueness/erratic situation in individualkindred (Kaman\& Hautaloma, 1975); patience forvagueness (Kealey\& Ruben, 1979) capable towards face newcircumstances (Popp\& Dean, 1990). 5-Analytic skills. According to research expatriate should use the communication \&linguisticcapabilitiesby way of important for cross-cultural erudition. These aptitudes arelinguisticassistances (Kaman, 1975); communiqué (Hammer, 1992)\& fluent in language (Shaffer, 1999).6-Taking action and initiative. Many researches showscreativityassistances as devisinganoptimistic impression, and just solitary research (Clarke, 1995) says a bad impression on erudition. Taking optimistic actions and initiative skill set involve not to be passive (Johnson,2006); making amendments in bad areas (Hautaloma, 1975) getting perils (Ratiu, 1983) taking actions (Kealey, 1989) choosing initiatives (Dunbar, 1992); \& having extrovert behavior (Parker \&McEvoy, 1993). Ishida (1992) and ultimate performance depends on right decisions. 7-Adaptability and flexibility. Expatriates should be adaptive and flexible personality wise. Such competencies was explained in research as flexibility-rigidity (Stoner, 1972); relational flexibility (Hawes \&Kealey, 1979, 1981). 8-Managing stress. Stress management skills means expatriates should be able to manage stress in complex situations that they are facing first time. Involvement in cross culture can create high level of tensions and experiences for expatriates; and expatriates should have such skills to deal with such situations. These number of skills have been explained in article as emotivemellowness to bear or control anxiety, despair, and solitude (Hautaloma, 1975; Stein, 1966)self-discipline while facing anxiety (Hawes, 1979) and promptly deal with stress (Ratiu, 1983). 


\section{Personality Traits}

Multiple traits plays important role in intercultural effectiveness. Here we can involve Patience, energy, courtesy, consistent with flexibility, maturity, and self-respect (Hannigan, 1990). Important area of collected workshas found the link among personality characters and émigré results. The analysis has done thru (Mol, 2005) and suggested that personacharacters are deeply connected with émigréenactment. Previous researchers also originate that personacharacters having great influence on cross cultural modification ( peltokorpi, 2008; Shaffer,2006). Studies have originate that persona\& emotional intelligence have distinctions although correlated constructs; each of them are connected byhispersonal different set of discretechanges (Ang, 2006) whereas persona traits are peculiarity discrete distinctiveness that define wide plus constant tendencies, emotional intelligence is state-similardistinct distinctions whose explain ductilecompetences, and actions to act successfully in cross ethnic (Ang,2006) on opposite side, actual little study has described mutuallytheoriescon currently about their influences on foreign ethnic modification, by different conclusions.

Characters whose areassociated estructively with cross cultural effectiveness containfussiness, ethnocentrism, firmness, reliantworry, future sloping behavior, introverts, and egocentric behavior (Hannigan, 1990). The intellectual segment of emotional intelligence identify with a person's learning of explicit standards, rehearses shows in anoverseasrepublic (Earley, 2003). It include crucial standards of the new culture, for example, how much an individual having data about the lawful and financial frameworks, rules of the unknown dialect, non-verbal correspondences, social qualities and strict convictions. It is confirmed that when an individual learn completely about a culture it will enable him behave and communicate accordingly with peoples living in that specific culture. And that will also enable him to completely adjust himself according to that culture. Motivational emotional intelligence tells about an individual's strives to learn about how he can work in other culture. It is considered as intrinsic motivation of an individual that he involves himself in cross cultural adjustments or experiencing cross cultural. Now it varies person to person that how much he is motivated in learning or experiencing new cultural. Motivational emotional intelligence is positively linked with cross cultural adjustments. (Ang, 2007; templer, 2006; kim, 2008;portnoyandchen, 2012; huff, 2013).

Behavioral emotional intelligence includes flexibility of a person in showing proper actions while contacting or making collaborations with persons from diversebeliefs people (Ang, 2007). Have suggested that interactive emotional intelligence linked with exertion. Behavioral emotional intelligence is actually a capability of anindividual to display proper vocal and non-vocal actions while contacting thru peoples and while communicating with peoples having different environment and cultures.

\section{Personality Characteristics as Predictor of Success}

Most of the researchers have concluded that expatriates those are having maximum performance and those are well adjusted in foreign countries are having some personality characteristics. (Wilson\& Dalton, 2000; \&Oddou \& Mendenhall, 1985; Caligiur, 2000b; Mol,2005;Shaffer,2006; Black, 1990). It's all depends on the personality traits of expatriates that how much he indulge himself in new culture for learning new norms, gathering cultural information, and making news relations and network in host country. Globalexpatriate'sachievement always depends on personality traits.Research have identified five personality traits (Goldberg. L, 1992, 1993;John\&McCrae, 1992) are;

- Sociability

- Conscientiousness

- Agreeableness

- Emotive Constancy

- Openness and Expatriates

We need to develop these traits for becoming successful in foreign country. These five traits are strongly important for expatriates for becoming a successful in assignments (viswesvaran, 1997, 1999;caligiuri, 2000a, b; Shaffer, 2006) also these must be comprised in the selections eligibility criteria for new expatriates (van, pater, 2005). E.g. organizations those are having higher conscientiousness will willing to be a good leader, want to become popular in the eyes of peoples, desire to get maximum salaries packages. Multiple researches explained that there is positive link between consciousness and expatriates performance in U.S (barrack and mount, 1991; day and silver man, 1989).

\section{Control Ability}

Now the framemanufacture and assemblage are important foreigntasks of TSMEs (chen and chen, 1998). "Control ability" can define as how well an expatriate can lead the nativeprocesses. (Liu and Jaw,2004) and similarlydiscover that duty of Taiwan émigrés is towardsregulatorplus lead the native country individuals near make it sure that local workers achieving manufactureobjectives effectively on behalf of showing best foreignenactment. 


\section{Autonomous Managerial Capability}

For SMEs, they need to more conscious about entrepreneurial activities (beamish\& Lu, 2001) andemigrants should remainpreserved as magnates and because numerousopportune decision they need to kind. Expatriate have to perform as an entrepreneur in his subsidiary and they are authorized to take decisions in favor of their subsidiaries. By using partialcapitals, émigrés belong to TSMEs are independent in the native country. Everyone accountable used for specific duty. These émigrés need to kind timely and frequently immediate conclusionsself-sufficientlydeprived of consulting with others.

\section{Cultural Responsiveness}

Hereinstudy, cultural responsiveness infers that "individual be able toconstrue one's surroundings in most effective manner and remainsubtle to ethosexact circumstances". The collected worksstates that traditional responsiveness belongs to intuitive discerning (oddou and medenhall, 1985), whose can affect the ultimate performance. According to research there is a relation among personality and expatriates performance (lievens, 2003; Shaffer, 2006) and modification of students at international level (ying and han, 2006) giving focus to cross cultural adjustment. There are few personality traits are which involves logical in quisitiveness (Cleveland, 1960) over enthusiasticshared alignment (Guthrie, 1967) plus further researchers (Sedlacekand Boyer, 1988, church,hannigan and viswesvaran, 1982; 1990; 1997) respectively had told are important for expatriates adjustment in foreign country.

The performance related to interpersonal interaction has involved building personal and social relation or interactions with peoples belong to host country, talk in local language, and promote group activities. When expatriates contact with host country individuals they build Social relations through personality trait of agreeableness (buss,1991) and agreeableness tell about interpersonal relations or interactions(mount, barrack and stewart,1998; organ and Ryan,1995) are the predictor of expatriates enactment (viswesvaran, 1997) plus expatriate adjustment in cross culture( Shaffer, 2006).

Further more emotiveconstancy, extroversion, and scrupulousness are belongs toward enactment on dimension involve relational interaction (Mount, 1998; Ryan and Organ, 1995) extrovert are the peoples who assert themselves and search ways to exploit social relations to achieve personal goal. Students having different cultures want to declare themselves in the direction of develop relations thru the scholars of national/foreign, Students those focus more in extroversion can be more successful (Huang, 2005; Han and ying, 2006).

Emotional stability have positively linked with performance on the dimension involve interpersonal relations. (Van and van, 2002) has sawemotivesteadiness is prognostic of earlsustenance and nonexistence of adversecommunal experience. Thoroughness is belongs towardenactment of asocialfauna (caligiuri, 2000). Scrupulousness is a rule to boost the popularity \& designation of an employee.

\section{Success of Expatriate}

Success of expatriates and also failure of expatriates can be judge as how much expatriate have contributed toward the mission and vision of a company (Dan Wanga, 2014). Two main personal traits of expatriates are emotional intelligence and cultural intelligence have great influence on expatriate's adjustment in host country (templer et al, 2006). Expatriates those are good at cultural intelligence it means they will be good in making interactions with other peoples and they able to resolve the problems that faced by their self in presenting nation or region (Kartikab, 2014). If expatriates have maximum international experience it means they will be good in developing attitude, behaviors, knowledge \& skills (Kartikab, 2014).that have positive influence on expatriates adjustment in foreign country (Dan Wanga, 2014).

In addition, expatriates adjustment is greatly influenced by family support and family adaptability. When expatriates get support from his family which will helps to expatriates to work in better way in foreign environment (caligiuri, 2000). Families of expatriates having good ability to adjust in new environment will helps the expatriates to do their work more effectively in new environment. And the parental interestand family to work conflict influence the expatriates adjustment in positive way, but this result don't support the hypothesis that shows family to work conflict and parental interest negatively influence the expatriates adjustment. This research is based on spillover theory (Kartikab, 2014).Parental interest and family to work conflict is a big challenge to motivate the expatriates to do hard work. And then the adjustment of expatriates will be deteriorated and negative consequences will occur.

Mentoring behavior \& social capital has great influence on adjustment of expatriates and their performance in positive way (Dan Wanga, 2014). Expatriates having higher social capital means having good social networks will positively affect the adjustment and performance. Mentoring behavior of expatriates help he to enhance networks which will enables expatriates to articulate his/her problems which he/she face in foreign country (templer et al, 2006). 
Expatriates adjustment have positive impact on performance which includes expatriates performance, innovative work, and organizational performance. Expatriates having good adjustment in new environment will be at higher level of performance (Shaffer and harrison.2001). Expatriates those are become successful in adjusting their self in new environment are performing their work more effectively (Kartikab, 2014).

The performance of organization is affected by the expatriate's adjustment that reduce the workplace conflicts (Dan Wanga, 2014) and organizational performance is positively affected by employees work satisfaction. When employees adjust in new environment then their performance will increase and it will enhance the organizational performance.

\section{Theoretical Framework}

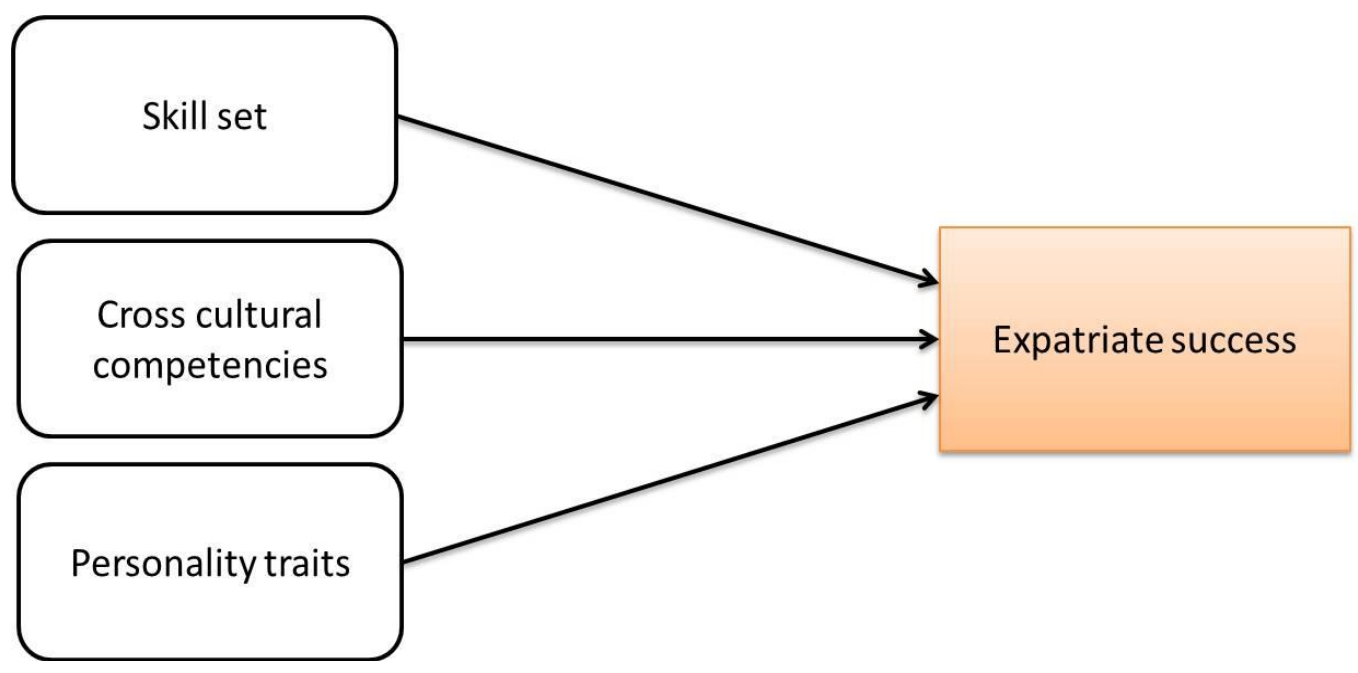

\section{Conclusion}

This review identifies the skill set, cross cultural competencies and personality traits to be a successful expatriate in cross cultural environment expatriate success is completing the given assignment and full filling the company expectations. Technical skills that are related to assignment and non-technical skills that are required to adjust communicate and build relationships with the peoples are also very important to be a successful expatriate. Results didn't backing the belongings of intuitive abilities taking place cross cultural competencies howeverit shows that intuitive abilities stimulus cross culture competencies specifically through communication(Dan Wanga, 2014). Some researches shows relational skills are very critical success factor for the performance of expatriates (Templer, 2010). Also studies show that only language fluency skill is not enough for expatriate because there are lot of other communication problems in the cross cultural environment. Cross-cultural competencies like making relations with others, valuing others, informational skills, analytical skills and tolerance to ambiguity are also critical for expatriate success in the cross cultural environment. Companies must design their expatriate training program to develop these skills in the expatriates.Expatriates become successful in their foreign assignment with the help of their personality characteristics like emotional and cultural intelligence and with the help of social capital which they have built their social network in host country. So these factors enables expatriates to become successful in host country andcomplete their foreign assignment in foreign country.

\section{References}

Alizee B .Avrial, v. P. (2007). a holistic aproch to expetriate sucess. international journal of contemporary hospitatlity Managment, 53-62.

Ang, S., Van Dyne, L., \& Koh, C. (2006). Personality correlates of the four-factor model of cultural intelligence. Group and Organization Management, 31,100-123.

Ang, S., Van Dyne, L., Koh, C., Ng, K., Templer, K. J., Tay, C., et al. (2007). Cultural intelligence: Its measurement and effects on cultural judgment and decisionmaking, cultural adaptation and task performance. Management and Organization Review, 3, 335-371.

Arthur W. Jr, Bennett W. Jr. (1995). The international as-signee: The relative importance of factors perceived to contribute to success. Personnel Psychology, 99-114

Barrick, M., \& Mount, M. (1991). The big five personality dimensions and job performance: A meta-analysis. Personnel Psychology, 44, 1-26. 
Black, J. (1990). The relationship of personal characteristics with adjustment of Japanese expatriate managers. Management International Review, 30, 119-134.

Black, J. S., \& Mendenhall, M. E. (1990). Cross-cultural training effectiveness: A review and a theoretical framework for future research. Academy of ManagementReview, 15, 113-136.

Boyer, S. P., \& Sedlacek, W. E. (1988). Noncognitive predictors of academic success for international students: A longitudinal study. Journal of College Student Development, 29, 218-223.

Brown, R. J. (2008). Dominant stressors on expatriate couples during international assignments. international Journal of Human Resource Management, 19(6), 1018-1034.

Buss, D. M. (1991). Evolutionary personality psychology. In Rosenzweig, M. R., \& Porter, L. W. (Eds.), Annual review of psychology. vol. 42 (pp.459-492).Palo Alto,CA: Annual Reviews Inc.

Byrnes F. C. (1965.) Americans in technical assistance: A study of attitudes and responses to their role abroad. New York: Frederick A. Praeger.

Caligiuri, P. (2000b). Selecting expatriates for personality characteristics: A moderating effect of personality on the relationship between host national contact and cross-cultural adjustment. Management International Review, $40,61-80$.

Caligiuri, P. M. (2000). The Big Five personality characteristics as predictors of expatriate's desire to terminate the assignment and supervisor-rated performance. Personnel Psychology, 53, 67-88.

Chen, H., \& Chen, T. J. (1998). Network linkages and location choice in foreign direct investment. Journal of International Business Studies, 29(3), 445-468.

Chen, X., Liu, D., \& Portnoy, R. (2012). A multilevel investigation of motivational Cultural Intelligence, organizational diversity climate and cultural sales:Evidence from U.S. real estate firms. Journal of Applied Psychology, 97, 93-106.

Church, A. (1982). Sojourner adjustment. Psychological Bulletin, 9, 540-572.

Clarke C., Hammer M. R. (1995). Predictors of Japanese and American managers' job success, personal adjustment, and intercultural interaction effectiveness. Management International Review, 153-170.

Cleveland H., Mangone J. G., Adams J. C. (1960). The overseasAmericans. New York: McGraw-Hill.

cross-cultural adjustment. Management International Review, 40, 61-80.

Dalton, M., \& Wilson, M. (2000). The relationship of the five-factor model of personality to job performance for a group of middle eastern international assignee Managers. Journal of Cross-Cultural Psychology, 18, 250-258.

Dan Wanga, T. F. (2014). Unpacking the "skill - cross-cultural competence" mechanisms:. International Business Review, 530-541.

Day, D., \& Silverman, S. (1989). Personality and job performance: Evidence of incremental validity. Personnel Psychology, 42, 25-36.

Dean O., Popp G. E. (1990). Intercultural communication effectiveness as perceived by American managers in Saudi Arabia and French Managers in the U.S. International Journal of Intercultural Relations, 14: 405-424

Digman, J. (1990). Personality structure: The emergence of the five factor model. Annual Review of Psychology, 41, 417-440.

Dunbar E. (1992). Adjustment and satisfaction of expatriate U.S. personnel. International Journal of Intercultural Relations, 16: 1-16

Earley, P. C., \& Ang, S. (2003). Cultural intelligence: Individual interactions across cultures. Stanford, CA: Stanford University Press.

Goldberg, L. (1992). The development of markers for the big-five factor structure. Psychological Assessment, 4, 26-42.

Goldberg, L. (1993). The structure of phenotypic personality traits. American Psychologist, 48, 26-34.

Guthrie, G. M., \& Zektick, I. (1967). Predicting performance in the Peace Corps. Journal of Social Psychology, 71, 1121.

Hannigan, T. P. (1990). Traits, attitudes, and skills that are related to intercultural effectiveness and their implications for cross-cultural training: a review of the literature . Inrernorronol Journal of Inrerculrural Relorrons, 89-111.

Harris J. G. Jr.. (1973). A science of the South Pacific. Analysis of the character structure of the Peace Corps volunteer. American Psychologist, 28(3): 232-247

Hautaloma J. E., Kaman V. (1975). Description of Peace Corps volunteers experience in Afghanistan. Topics in Cultural Learning, 79-96.

Hawes F., Kealey D. J. (1979). Canadians in development: An empirical study of adaptation and effectiveness on overseas assignment, technical report. Ottawa, Canada: Canadian International Development Agency.

Huang, T., Chi, S., \& Lawler, J. J. (2005). The relationship between expatriates' personality traits and their adjustment to international assignments. International Journal of Human Research Management, 16, 1656-1670. 
Huff, K. (2013). Language, cultural intelligence, and expatriate success. Management Research Review (advance online publication).International Journal of Human Resource Management, 19(7), 1298-1313.

Ishida H. (1992). Kokusai keiei no ninngen mondai (2nd ed.). Tokyo, Japan: Keio Tsushin.International Journal of Intercultural Relations, 26, 679-694.

Jaw, B. S., \& Liu, W. (2004). Toward an integrative framework of strategic international human resource control: the case of Taiwanese subsidiaries in the People's Republic of China. International Journal of Human Resource Management, 15(4), 705-729.

Johnson, J. P. (2006). Cross-cultural competence in international business: Toward a definition and a model. Journal of International Business Studies, 525-543.

Kartikab, L.-Y. L. (2014). The influence of individual, family, and social capital factors on expatriate adjustment and performance: The moderating effect of psychology contract and organizational support. Expert Systems with Applications, 5483-5494.

Kealey D. J. (1989). A study of cross-cultural effectiveness: Theoretical issues, practical applications. International Journal of Intercultural Relations,387-428.

Khan, A., Khan, R., \& Rahman, M. H. (2011). Developing international executives: TheJournal of Human Research Management, 16, 1656-1670.

Kim, K., Kirkman, B. L., \& Chen, G. (2008). A process model of cultural intelligence on expatriate job performance. In Paper presented at the Society for Industrialand Organizational Psychology San Francisco.

Lievens, F., Harris, M. M., Van Keer, E., \& Bisqueret, C. (2003). Predicting cross-cultural training performance: The validity of personality, cognitive ability, andManagers. Journal of Cross-Cultural Psychology, 18, 250-258.

Lu, J. W., \& Beamish, P. W. (2001). The Internationalization and performance of SMEs. Strategic Management Journal, 22(6/7), 565-586.

McCrae, R., \& Costa, P. (1987). Validation of the five factor model of personality across instruments and observers. Journal of Personality and Social Psychology, 52, 81-90.

McCrae, R., \& Costa, P., Jr. (1989). The structure of interpersonal traits: Wiggins's circumplex and the five-factor model. Journal of Personality and Social Psychology,56, 586-595

McCrae, R., \& John, O. (1992). An introduction to the five factor model and its application. Journal of Personality, 60, 75-215.

Mendenhall, M., \& Oddou, G. (1985). The dimensions of expatriate acculturation: A review. Academy of Management Review, 10, 39-47.

Mol, S. T., Born, M. Ph., Willemsen, M. E., \& Van Der Molen, H. T. (2005). Predicting, expatriate job performance for selection purposes; a quantitative review.Journal of Cross-Cultural Psychology, 36(5), 590-620.

Mount, M. K., Barrick, M. R., \& Stewart, G. L. (1998). Five-factor model of personality and performance in jobs involving interpersonal interactions. Human Performance, 11, 145-165.

Ones, D. S., \& Viswesvaran, C. (1997). Personality determinants in the prediction of aspects of expatriate job success. In Saunders, Z., New approaches to employee management. vol. 4 (pp.63-92). Greenwich, CT: JAI Press Inc.

Ones, D., \& Viswesvaran, C. (1999). Relative importance of personality dimensions for international assignee selection: A policy capturing study. HumanPerformance, 12, 275-294.

Organ, D. W., \& Ryan, K. (1995). A meta-analytic review of attitudinal and dispositional predictors of organizational citizenship behavior. Personnel Psychology, 48,775-802.

Parker B., McEvoy G. M.( 1993). Initial examination of a model of intercultural adjustment. International Journal of Intercultural Relations, 17: 355-379

Peltokorpi, V. (2008). Cross-cultural adjustment of expatriates in Japan. The International Journal of Human Resource Management, 19(9), 1588-1606.

Porter G., Tansky J. W. (1999). Expatriate success may depend on a learning orientation: Considerations for selection and training. Human Resource Management, 47-60.

Ratiu I. (1983). Thinking internationally: A comparison of how international executives learn. International Studies of Management and Organization, 139-150

Ruben B. D., Kealey D. J. (1979). Behavioral assessment of communication competency and the prediction of crosscultural adaptation. International Journal of Intercultural Relations, 15-47.

Seak, N., \& Enderwick, P. (2008). The management of New Zealand expatriates in China.

Shaffer M. A., Harrison D. A., Gilley K. M. (1999). Dimensions, determinants, and difference in the expatriate adjustment process. Journal of International Business Studies, 557-581

Shaffer, M. A., Harrison, D. A., Gregerson, H., Black, J. S., \& Ferzandi, L. A. (2006). You can take it with you: Individual differences and expatriate effectiveness.Journal of Applied Psychology, 91(1), 109-125. 
Samovar, L. A., Porter, R. E., \& Jain, N. C. (1981). Understanding intercultural communication. Belmont, CA: Wadsworth Publishing Company.

Stein M. I. (1966). Volunteers for peace: The first group of Peace Corps volunteers in a rural community development program in Columbia, South America. New York: John Wiley \& Sons.

Stening B. W., Hammer M. R. (1992). Cultural baggage and the adaptation of expatriate American and Japanese managers. Management International Review, 77-89.

Stoner J. A. F., Aram J. D., Rubin I. M. (1972). Factors associated with effective performance in overseas work assignments. Personnel Psychology, 25(2), 303-318

Templer, K., Tay, C., \& Chandrashekar, N. A. (2006). Motivational cultural intelligence, realistic job preview, realistic living conditions preview and cross-cultural adjustment. Group and Organization Management, 31, 154-171.

Tung R. L. (1998). American expatriates abroad: From neophytes to cosmopolitans. Journal of World Business,125144

Van Oudenhoven, J. P., \& Van der Zee, K. I. (2002). Predicting multicultural effectiveness of international students: The Multicultural Personality Questionnaire.

Van Vianen, A., De Pater, I. E., \& Caligiuri, P. (2005). Expatriate selection: A process. refereed book chapter. In A. Evers, O. Smit-Voskuyl, \& N. Anderson (Eds.), Thehandbook of personnel selection Oxford: Blackwell.

Ward, C., Fischer, R., Lam, R. S. Z., \& Hall, L. (2009). The convergent, discriminant, and Incremental Validity of scores on a self-report measure of culturalintelligence. Educational and Psychological Measurement, 69(1), $85-105$.

Welch, D. E.,Welch, L. S., \& Piekkari, R. (2005). Speaking in tongues: The importance of language in international management processes. International Studies of Management and Organization, 35(1), 10-27.

Ying, Y., \& Han, M. (2006). The contribution of personality, acculturative stressors, and social affiliation to adjustment: A longitudinal study of Taiwanese studentsin the United States. International Journal of Intercultural Relations, 30, 623-635

Yoshitaka yamazaki, D. C. (2004). An Experiential Approach to Cross-Cultural Learning: A Review and Integration of Competencies for Successful Expatriate Adaptation. Academy of Management Learning \& Education, 362379. 